\title{
Operacijsko liječenje koštanohrskavičnih oštećenja talusa u djece
}

\author{
Ivan Bojanić, Andrija Jurina, Damjan Dimnjaković, Tomislav Smoljanović*
}

\begin{abstract}
U medicinskoj literaturi malo je dostupnih podataka o operacijskom liječenju koštanohrskavičnih oštećenja talusa (engl. Osteochondral Lesion of the Talus, OLT) u djece. Cilj ovog istraživanja bio je evaluirati srednjoročne rezultate liječenja OLT-a artroskopskom stimulacijom koštane srži (engl. Bone Marrow Stimulation, BMS) tehnikom mikrofraktura u djece kod koje u trenutku operacijskog zahvata nije bila dostignuta koštana zrelost. U istraživanju je sudjelovalo 13-ero djece s dijagnosticiranim OLT-om koja su liječena artroskopskom BMS tehnikom mikrofraktura, a kod koje su u trenutku operacijskog zahvata epifizne pukotine rasta bile otvorene. Na zadnjem kontrolnom pregledu ispitanici su procijenili stanje operiranog gležnja pomoću Berndt and Harty (BH), Single Assessment Numeric Evaluation (SANE) i Martin upitnika. Funkcionalno stanje gležnja evaluirano je American Orthopaedic Foot and Ankle Society (AOFAS) upitnikom. Upitnik Short Form 36 (SF 36) primjenjen je za procjenu kakvoće života povezane sa zdravljem. Medijan životne dobi ispitanika u trenutku zahvata iznosio je 15 (13-16) godina, a medijan praćenja u poslijeoperacijskom razdoblju 5,6 (3,8-13,6) godina. Prema BH upitniku ishod liječenja je u 10-ero bolesnika ocijenjen kao dobar, a kod troje zadovoljavajući. Kod 11 -ero ispitanika rezultati su prema SANE upitniku ocijenjeni kao izvrsni ili dobri. Utvrđeno je značajno poboljšanje poslijeperacijskog AOFAS skora u odnosu na prijeoperacijski AOFAS skor, a prosječna razlika je iznosila 35 bodova. Medijan zbirne komponente tjelesnog i mentalnog zdravlja SF 36 upitnika nalazio se u normalnim granicama za hrvatsku populaciju. Artroskopska BMS tehnika mikrofraktura pouzdana je i učinkovita operacijska metoda za liječenje OLT-a u djece kod koje nije dostignuta koštana zrelost.
\end{abstract}

Ključne riječi: artroskopija; talus; djeca

UVOD

Koštanohrskavično oštećenje talusa (engl. Osteochondral Lesion of the Talus, u daljnjem tekstu OLT) Iokalizirano je oštećenje koje zahvaća zglobnu površinu talusa, a očituje se aseptičkim odvajanjem komadića hrskavice s ili bez dijela pripadajuće subhondralne kosti. Valja istaknuti da je tradicionalni naziv za ovo stanje osteohondritis disekans talusa, no budući da upalna etiologija bolesti nikad nije dokazana, posljednjih se godina u medicinskoj literaturi umjesto tog naziva savjetuje uporabu termina koštanohrskavično oštećenje talusa.

Izbor najprikladnijeg načina liječenja OLT-a ponajviše ovisi o odvojenosti koštanohrskavičnog fragmenta od kosti, a na osnovi te odvojenosti zasnivaju se i radiološke klasifikacije. Kod oštećenja I. i Il. stupnja prema Berndt i Hartijevoj klasifikaciji liječenje se savjetuje započeti neoperacijskim metodama, u prvom redu imobilizacijom te modifikacijom tjelesnih aktivnosti (1). U slučaju neuspjeha neoperacijskog liječenja te kod oštećenja III. i IV. stupnja preporučuje se provesti operacijsko liječenje $(2,3)$. Metode operacijskog liječenja su: stimulacija koštane srži (engl. Bone Marrow Stimulation, u daljnjem tesktu BMS), fiksacija koštanohrskavičnog fragmenta, prijenos autogenog koštanohrskavičnog presatka (engl. Osteochondral Autograft Transfer System), implantacija autolognih hondrocita (engl. Autologous Chondrocyte Implantation) i transplantacija alogenog koštanohrskavičnog presatka (engl. Osteochondral Allograft Transplantation). U današnje vrijeme artroskopski BMS (bušenjem ili tehnikom mikrofraktura) primarna je metoda za operacijsko liječenje OLT-a kod odraslih bolesnika, jer se nakon višegodišnjeg praćenja dobri ili izvrsni rezultati nala-

\footnotetext{
* KBC Zagreb, Klinika za ortopediju, Šalata 7, 10000 Zagreb
}

\section{Adresa za dopisivanje:}

Prim. dr. sc. Ivan Bojanić, KBC Zagreb, Klinika za ortopediju, Šalata 7, 10000 Zagreb, e-mail: ivan.bojanic@mef.hr

Primljeno/Received: 14. 4. 2015., Prihvaćeno/Accepted: 3. 8. 2015. 
ze u $85 \%$ bolesnika, a osim toga ova je metoda jeftina, minimalno invazivna te omogućuje brz oporavak bolesnika (4, 5). Ostale metode u najvećem broju slučajeva zahtijevaju otvoreni kirurški pristup i češće su povezane s komplikacijama kao što su otežano cijeljenje rane, morbiditet na mjestu uzimanja presatka te nesrastanje mjesta osteotomije maleola koja je vrlo često potrebna za pristup OLT-u. Stoga se upotreba tih metoda savjetuje u slučajevima neuspjeha liječenja artroskopskom BMS tehnikom mikrofraktura te kod OLT-a visokog stupnja sa značajnim subhondralnim cistama (4).

U djece kod koje nije dostignuta koštana zrelost operacijsko liječenje nameće se kao osnova zbrinjavanja OLT-a, s obzirom na to da su rezultati nakon provedenog neoperacijskog liječenja kontroverzni (6-10). Nažalost, malen je broj istraživanja koja su evaluirala učinkovitost metoda operacijskog liječenja ciljano u djece kod koje u trenutku operacijskog zahvata nije bila dostignuta koštana zrelost. Ipak, prema dostupnim rezultatima, BMS i fiksacija koštanohrskavičnog fragmenta čine se prihvatljivim opcijama (8-11).

Svrha ovog istraživanja bila je evaluirati srednjoročne rezultate liječenja OLT-a artroskopskom BMS tehnikom mikrofraktura u djece kod koje u trenutku operacijskog zahvata nije bila dostignuta koštana zrelost.

\section{ISPITANICI I METODE}

Od 1999. godine se u Klinici za ortopediju KBC-a Zagreb primjenjuje artroskopska BMS tehnika mikrofraktura u liječenju bolesnika s OLT-om. Pretraživanjem operacijskih protokola Klinike s pomoću ključnih riječi "artroskopija", "osteohondritis disekans" i "talus", pronađeno je 123-oje bolesnika (127 gležnjeva) operiranih u razdoblju od 1. siječnja 1999. do 1. siječnja 2013. godine. Medicinsku dokumentaciju svih bolesnika potom je pregledao liječnik koji nije sudjelovao u njihovom liječenju. Od navedenih bolesnika u istraživanje su uključena djeca (djevojčice $\leq 15$ godina, dječaci $\leq 16$ godina) kod koje u trenutku operacijskog zahvata nije bila dostignuta koštana zrelost (Slika 1). Kriteriji izbora ispitanika zasnivali su se na istraživanju Karrholma i sur., u kojem je utvrđeno da do zatvaranja epifiznih zona rasta u distalnom dijelu tibije kod djevojčica prosječno dolazi sa 15 godina, a kod dječaka sa 16 godina (12). Bolesnici koji su prethodno već imali operacijski zahvat na promatranom gležnju isključeni su iz istraživanja. Temeljem navedenih kriterija izdvojeno je 14-ero ispitanika. Svi su telefonski kontaktirani i pozvani da sudjeluju u istraživanju. 13-ero ispitanika je pristalo na sudjelovanje te su dogovoreni termini kontrolnih pregleda. Na kontrolnom pregledu svi su ispitanici potpisali informirani pristanak, ispunili upitnike u kojima su subjektivno procijenili stanje operiranog gležnja, a po- tom ih je pregledao liječnik koji nije bio uključen u njihovo liječenje. Ovo je istraživanje odobrilo Etičko povjerenstvo Kliničkog bolničkog centra Zagreb.

\section{Operacijska tehnika}

U svih je ispitanika isti operater (I.B.) načinio artroskopski kirurški zahvat na gležnju na isti način. Svi su bolesnici bili u spinalnoj anesteziji, u položaju na leđima i s uspostavljenom blijedom stazom na natkoljenici noge koja će se operirati. Svi su perioperacijski dobivali antitrombotsku i antibiotsku profilaksu (cefalosporin II. generacije). Kod svih su bolesnika načinjeni standardni anteromedijalni i anterolateralni ulazi na gležnju, pa se nakon čišćenja prednjeg dijela zgloba, čime podrazumijevamo djelomičnu sinoviektomiju i uklanjanje eventualno prisutnih osteofita s prednjeg distalnog ruba tibije, pristupilo OLT-u. Kod svih je bolesnika nađen nestabilan koštanohrskavični fragment, koji je kod dijela bolesnika bio i odvojen od koštanog ležišta, pa se nakon njegova uklanjanja pristupalo čišćenju ležišta, i to dijelom motoriziranim instrumentom, a dijelom kohlejama. Pošto je postignuto stabilno ležište s čistom subhondralnom košću, prstenastom je kiretom načinjen oštar, okomiti rub prema području zdrave hrskavice. Potom su u ležištu učinjene mikrofrakture posebnim instrumentarijem do dubine od 5 $\mathrm{mm}$, razmaknute 3 do $4 \mathrm{~mm}$, i to sustavno, najprije sve rubne, a tek potom su učinjene i one prema središtu. U svih je bolesnika gležanj dreniran, a rane zašivene neresorptivnim koncem. Nakon 24 sata dren je izvađen i tada se postupno započinjalo s vježbama razgibavanja operiranoga gležnja i onim za cirkulaciju. Tijekom prvih šest tjedana bolesnici su hodali uz pomoć podlaktičnih štaka, opterećujući pritom operiranu nogu do $10 \mathrm{~kg}$ tjelesne mase. Tijekom idućih šest tjedana, bolesnici su također hodali pomoću štaka, postupno povećavajući opterećenje, i to tijekom dvaju prvih tjedana maksimalno do trećine svoje tjelesne mase, tijekom sljedeća dva do dvije trećine, da bi tijekom posljednjih dvaju tjedana tog razdoblja operiranu nogu opterećivali punom tjelesnom masom i postupno odbacivali štake. Bolesnicima je dopušteno trčanje pet mjeseci nakon obavljenog zahvata, a puna športska aktivnost, ovisno o športu i tijeku rehabilitacije, između šestog i osmog mjeseca.

\section{Instrumenti u istraživanju}

Na kontrolnom pregledu provedenom u sklopu istraživanja sve je bolesnike pregledao liječnik koji nije sudjelovao u njihovom liječenju. Objektivna procjena funkcionalnog stanja operiranog gležnja obavljena je American Orthopaedic Foot and Ankle Society (u daljnjem tesktu AOFAS) upitnikom, a dobiveni poslijeoperacijski AOFAS skor uspoređen je s onim prijeoperacijskim (13). Svi su ispitanici subjektivno 


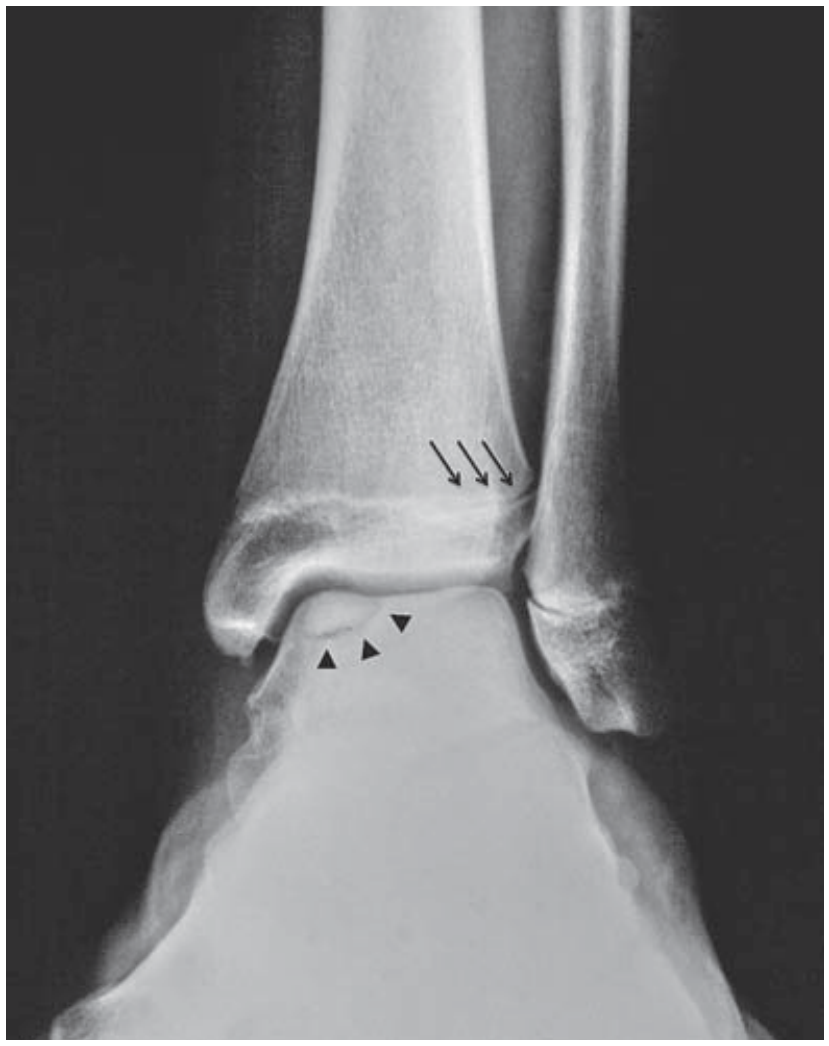

Legenda: strjelice - otvorene epifizne pukotine rasta u distalnom dijelu tibije, vršci strjelica - anteromedijalna lokalizacija koštanohrskavičnog oštećenja talusa

SLIKA 1. Prijeoperacijska radiološka anteroposteriorna snimka lijevog gležnja u položaju povišene pete (engl. heel-raised)

procijenili stanje operiranog gležnja, ispunjavajući upitnike Single Assessment Numeric Evaluation (u daljnjem tesktu SANE), Berndt and Harty (u daljnjem tekstu BH) te Martin (1, 14, 15). SANE upitnik sastoji se od jednog pitanja kojim ispitanici trebaju ocijeniti funkciju promatranog gležnja na ljestvici od 0-100. Odgovori se potom klasificiraju kao izvrstan (95-100), dobar (80-94), zadovoljavajući (65-79) ili loš (<65). Prema BH upitniku ispitanik stanje operiranog gležnja ocjenjuje kao dobro, zadovoljavajuće ili loše. Dobro označuje stanje bez simptoma ili prisutnost blagih simptoma koji ne utječu na funkciju gležnja, zadovoljavajućim se smatra poboljšanje simptoma, no uz određeni stupanj nesposobnosti, dok loše stanje navodi na mišljenje da nije uopće došlo do poboljšanja simptoma nakon provedenog liječenja. Upitnik Martin je razdijeljen u sedam kategorija: bol, oteklina, ukočenost, poslijeoperacijsko poboljšanje, šepanje, aktivnost i osjećaj nestabilnosti. Ispitanik se kod svake kategorije opredjeljuje za jedan od četiri ponuđena odgovora. Ovisno o najlošije rangiranom odgovoru, stanje gležnja ocjenjuje se kao izvrsno, dobro, zadovoljavajuće ili loše. Kakvoća života ispitanika povezana sa zdravljem procijenjena je hrvatskom verzijom upitnika Short Form 36 (u daljnjem tekstu SF 36) (16). Upitnik se sastoji od 36 pitanja koja pokri-

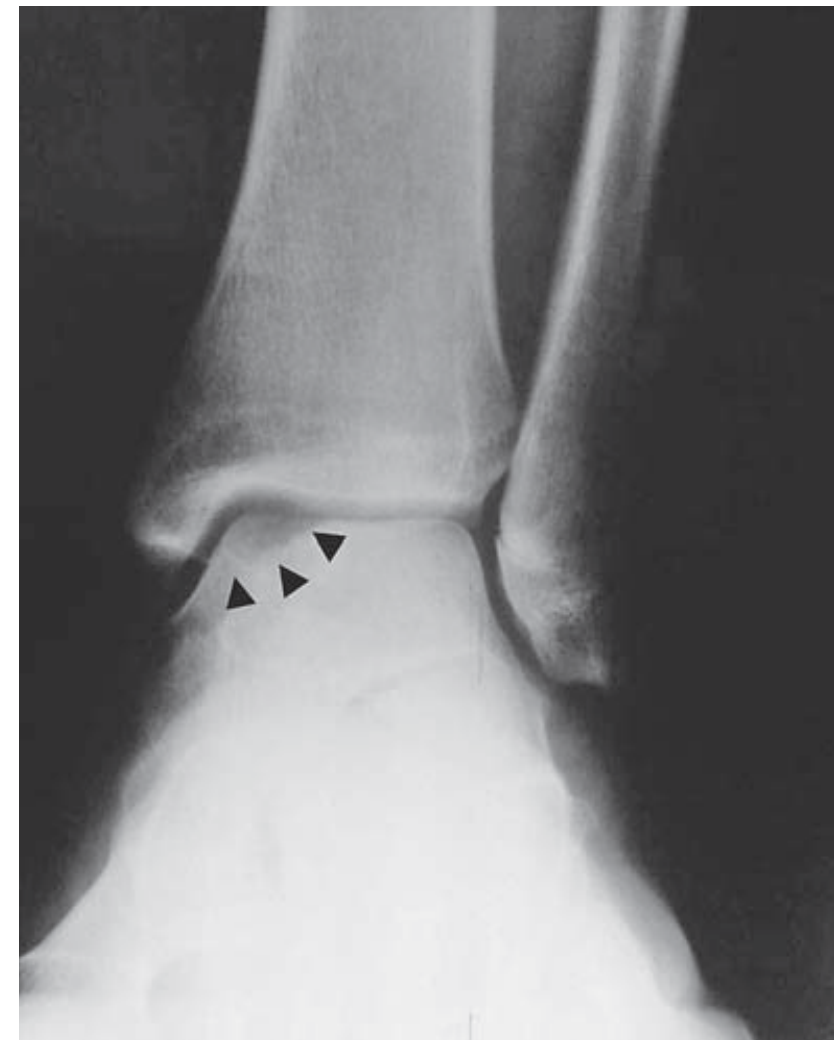

Legenda: vršci strjelica - lokalizacija fibrokartilaginoznog tkiva $\mathrm{u}$ anteromedijalnom dijelu talusa

SLIKA 2. Poslijeoperacijska radiološka anteroposteriorna snimka lijevog gležnja

vaju osam mjera zdravlja: fizičko funkcioniranje, ograničenja zbog fizičkog zdravlja, tjelesni bolovi, opće zdravlje, vitalnost, socijalno funkcioniranje, ograničenja zbog emocionalnih problema i duševno zdravlje. Navedenih osam mjera zdravlja moguće je dodatno podijeliti u dvije skupine te izračunati zbirnu komponentu tjelesnog zdravlja (engl. Physical Common Score, PCS) i zbirnu komponentu mentalnog zdravlja (engl. Mental Common Score, MCS).

\section{REZULTATI}

Istraživanje je obuhvatilo 13-ero ispitanika, šest djevojčica sedam dječaka, a medijan njihove životne dobi u trenutku zahvata iznosio je 14 godina (raspon od 13 do 16 godina) Inicijalna ozljeda gležnja anamnestički je utvrđena u sedam $(53,8 \%)$ slučajeva, a medijan trajanja simptoma do postavljanja dijagnoze OLT-a je bio 12 mjeseci (raspon od 6 do 60 mjeseci). Kod svih bolesnika mjesto koštanohrskavičnog oštećenja kupole talusa nađeno je standardnom radiološkom obradom, pri čemu je medijalna lokalizacija OLT-a dijagnosticirana u 11-ero (84,6\%), a lateralna u dvoje (15,4\%) ispitanika. Jedno je oštećenje $(7,7 \%)$ prema Berndt i Hartijevom klasifikacijskom sustavu bilo ocijenjeno kao II. stupanj, 
TABLICA 1. Ishod liječenja OLT-a u djece nakon artroskopske stimulacije koštane srži tehnikom mikrofraktura

\begin{tabular}{|c|c|}
\hline Naziv upitnika & Broj ispitanika = 13 \\
\hline \multicolumn{2}{|l|}{ AOFAS } \\
\hline $\begin{array}{l}\text { Prijeoperacijski skor - medijan (raspon) } \\
\text { Poslijeoperacijski skor - medijan (raspon) }\end{array}$ & $\begin{array}{l}56(50-61) \\
90(77-100)\end{array}$ \\
\hline $\mathrm{BH}$ & $\begin{array}{l}10 \text { Dobar } \\
3 \text { Zadovoljavajuć } \\
0 \text { Loš }\end{array}$ \\
\hline SANE & $\begin{array}{l}4 \text { Izvrstan } \\
7 \text { Dobar } \\
2 \text { Zadovoljavajuć } \\
0 \text { Loš }\end{array}$ \\
\hline Martinov upitnik & $\begin{array}{l}0 \text { Izvrstan } \\
7 \text { Dobar } \\
6 \text { Zadovoljavajuć } \\
0 \text { Loš }\end{array}$ \\
\hline \multicolumn{2}{|l|}{ SF-36 } \\
\hline $\begin{array}{l}\text { PCS - medijan (raspon) } \\
\text { MCS - medijan (raspon) }\end{array}$ & $\begin{array}{l}50,3(26,8-63,1) \\
51,7(39,7-64,0)\end{array}$ \\
\hline \multicolumn{2}{|c|}{$\begin{array}{l}\text { Legenda: OLT - koštanohrskavično oštećenje talusa (Osteochondral Lesion } \\
\text { of the Talus), AOFAS - upitnik za procjenu stanja gležnja (American } \\
\text { Orthopaedic Foot and Ankle Society score), SANE - upitnik za procjenu } \\
\text { stanja gležnja (Single Assessment Numeric Evaluation), SF-36 - kratki } \\
\text { upitnik od } 36 \text { pitanja za procjenu zdravlja (Short Form } 36 \text { questionnaire), } \\
\text { PCS - zbirna komponenta tjelesnog zdravlja (Physical Common Score), } \\
\text { MCS - zbirna komponenta mentalnog zdravlja (Mental Common Score) }\end{array}$} \\
\hline
\end{tabular}

deset $(76,9 \%)$ kao III. i dva $(15,4 \%)$ kao IV. stupanj. Radi pomoći u prijeoperacijskom planiranju kod osmero je bolesnika učinjena računalna tomografija, a kod troje magnetska rezonancija gležnja (u daljnjem tekstu MR). Medijan praćenja bolesnika u poslijeoperacijskom razdoblju bio je 5,6 godina (raspon od 3,8 do 13,6). U svih 13-ero ispitanika operacijski zahvat protekao je bez komplikacija, a one nisu zabilježene ni u poslijeoperacijskom razdoblju.

Značajno poboljšanje poslijeoperacijskog AOFAS skora zabilježeno je u odnosu na onaj prijeoperacijski $(p<0,01)$ (Tablica 1). Prema BH upitniku ishod liječenja je u desetero $(76,9 \%)$ bolesnika ocijenjen kao dobar, a kod troje $(23,1 \%)$ zadovoljavajući. Rezultati liječenja su prema SANE upitniku kod 11-ero $(84,6 \%)$ bolesnika ocijenjeni kao izvrsni ili dobri. Dobar ishod liječenja prema Martinovom upitniku utvrđen je u sedmero $(53,8 \%)$ bolesnika, a zadovoljavajući kod njih šestero (46,2\%). Medijan samoprocijenjenog tjelesnog i mentalnog zdravlja ispitanika izračunan upitnikom SF-36 nalazio se u normalnim granicama za hrvatsku populaciju (17).

\section{RASPRAVA I ZAKLJUČCI}

$U$ našem istraživanju 13-ero djece $s$ dijagnosticiranim OLT-om, kod koje u trenutku kirurškog zahvata nije bila dostignuta koštana zrelost, liječeno je artroskopskom BMS tehnikom mikrofraktura. Nakon srednjoročnog vremena pra- ćenja (medijan 5,6 godina) zabilježeno je značajno poboljšanje funkcionalnog stanja gležnja, mjerenog upitnikom AOFAS. Većina ispitanika subjektivno je ocijenila stanje operiranog gležnja kao dobro, pri čemu nije evidentiran nijedan loš ishod.

Brojne su metode liječenja OLT-a predložene u literaturi, a odluka o načinu liječenja - neoperacijsko vs. operacijsko, u prvom redu ovisi o stupnju odvojenosti koštanohrskavičnog fragmenta od kosti, koji se određuje prema Berndt i Hartijevoj klasifikaciji $(1,4)$. U novije se vrijeme za dijagnozu, prijeoperacijsko planiranje te poslijeoperacijsko praćenje OLT-a savjetuje obaviti MR kojim se uz određivanje stupnja odvojenosti koštanohrskavičnog fragmenta omogućuje i uvid u ostale karakteristike oštećenja (18-22). lako trenutno nema jasnih smjernica o liječenju OLT-a za svaki pojedini stupanj, postoji konsensus o tome da oštećenja I. stupnja treba započeti liječiti neoperacijskim metodama u trajanju od tri do šest mjeseci. Nakon neuspjeha neoperacijskog liječenja te u slučaju akutnog oštećenja s pomakom fragmenta (IV. stupanj), potrebno je provesti operacijsko liječenje. Brojne se rasprave još i sad vode o tome koja to oštećenja II. i III. stupnja, s obzirom na njihove karakteristike, treba početi liječiti neoperacijskim, a koja operacijskim metodama (1-3). Važno je istaknuti da su postojeće smjernice namijenjene u prvom redu za liječenje odraslih bolesnika, no zbog nedostatnog broja istraživanja koja su evaluirala rezultate liječenja ciljano u dječjoj dobi, ta su načela preuzeta i za liječenje OLT-a kod djece (8-10, 23).

Neoperacijsko liječenje OLT-a sastoji se od imobilizacije zahvaćenog gležnja te modifikacije tjelesnih aktivnosti. Budući da u djece kod koje nije dostignuta koštana zrelost postoji pojačani potencijal cijeljenja OLT-a, dio autora savjetuje da se sva oštećenja I.-III. stupnja počnu liječiti neoperacijski, a da se u slučaju neuspjeha nakon preporučenog šestomjesečnog liječenja ono može nastaviti i do godinu dana (9, 10, 23). Ipak, dostupni rezultati o provedenom neoperacijskom liječenju nisu dosljedni. Tako su primjerice Higueira i sur. te Lam i sur. izvijestili o dobrim ili izvrsnim kliničkim rezultatima kod 11-ero (91\%), odnosno šestero (100\%) ispitanika, dok su s druge strane Letts i sur. te Perumal i sur. objavili da je uspjeh neoperacijskog liječenja u njihovim istraživanjima postignut u samo devetero (46\%), odnosno petero (16\%) ispitanika (6-9). Napose valja istaknuti rezultat istraživanja Reilingha i sur. objavljenog 2013. godine, gdje je čak 92\% inicijalno neoperacijski liječene djece na kraju bilo operirano (10). Već su i ovi rezultati vrlo zabrinjavajući, a još valja napomenuti da u pojedinih bolesnika, unatoč kliničkom poboljšanju, ne dolazi do zadovoljavajućeg radiološkog cijeljenja oštećenja, što u kasnijoj dobi može dovesti do razvoja OLT-a s pomakom fragmenta (IV. stupanj), kao i uznapredovalog razvoja degenerativnih promjena u smislu 
osteoartritisa $(9,23)$. Stoga se čini kako preporučeno trajanje neoperacijskog liječenja od 3 do 6 mjeseci često nije dovoljno za potpuno cijeljenje oštećenja, a produljenje liječenja do godinu dana za ispitanike u ovoj životnoj dobi iznimno je zahtjevno.

U medicinskoj literaturi postoji mali broj istraživanja o rezultatima operacijskog liječenja OLT-a, a koja su provedena isključivo na dječjoj populaciji ili u kojima su djeca činila veći dio ispitanika. Dvije su metode istaknute kao primarne opcije operacijskog liječenja OLT-a u djece, a to su BMS bušenjem ili tehnikom mikrofraktura te fiksacija koštanohrskavičnog fragmenta $(8,11)$. Valja istaknuti da u tim istraživanjima postoje značajne varijacije, i to kako u smislu nejednakog izvođenja zahvata u svih ispitanika i različito provedene rehabilitacije u njih, tako i u smislu kratkog vremena praćenja te upotrebe upitnika kojima je ocijenjeno stanje operiranog gležnja. U našem istraživanju evaluirali smo srednjoročne rezultate liječenja OLT-a, pri čemu je kod svih bolesnika izveden kirurški zahvat na isti način, artroskopskom BMS tehnikom mikrofraktura. Prema BH upitniku, koji je u dosadašnjim istraživanjima najčešće primjenjivan kao mjera uspješnosti liječenja, rezultati su ocijenjeni kao dobri u desetero $(76,9 \%)$ bolesnika, a kod troje $(23,1 \%)$ kao zadovoljavajući. Letts i sur. objavili su rezultate liječenja BMS-om u 12-ero djece (11 artrotomija i samo jedna artroskopija), a raspodjela ishoda prema BH ljestvici bila je: dobar rezultat kod šestero (50\%), zadovoljavajući u petero (45\%) te loš kod jednog (5\%) bolesnika (8). Reilingh i sur. izvijestili su kako je od ukupnog broja bolesnika koji su liječeni BMS tehnikom mikrofraktura, u njih 13-ero (62\%) stanje prema BH ljestvici ocijenjeno kao dobro, kod troje (14\%) zadovoljavajuće, a kod petero loše (24\%) (10). Medijan praćenja bolesnika u tom istraživanju iznosio je četiri godine (raspon od jedne do 12 godina), dok je u našem bio 5,6 godina (raspon od 3,8 do 13,6 godina). Za razliku od našeg istraživanja u kojem je bolesnicima tijekom prvih šest tjedana nakon operacijskog zahvata dopušteno opterećivati operiranu nogu najviše do 10 kg tjelesne mase, bolesnici su u ovom istraživanju već u drugom i trećem tjednu postupno povećavali opterećenje operirane noge, da bi već šest tjedana nakon zahvata opterećivali nogu punom masom. Medijan poslijeoperacijskog AOFAS skora u tom je istraživanju iznosio 95 (raspon od 45 do 100) bodova, dok je u našem bio 90 (raspon od 77 do 100) bodova.

Neki autori savjetuju činiti fiksaciju koštanohrskavičnog fragmenta, i to napose u slučaju kad postoji veći fragment $(10,24)$. No u djece kod koje nije dostignuta koštana zrelost valja uvijek imati na umu da bi se taj zahvat morao obaviti bez osteotomije medijalnog maleola. U istraživanju Reilingha i sur. devetero djece s OLT-om II.-IV. stupnja liječeno je fiksacijom, pri čemu je prema BH upitniku kod sedmero ispi- tanika postignut dobar rezultat, a kod dvoje zadovoljavajući. $\mathrm{U}$ tom istraživanju trauma u anamnezi registrirana je u 49\% ispitanika, pri čemu je 76\% oštećenja bilo medijalne, a 24\% lateralne lokalizacije (10). U našem istraživanju 11(84,6\%) oštećenja bilo je smješteno medijalno, a dva (15,4\%) lateralno, dok je trauma u anamnezi zabilježena kod 53,8\% ispitanika. Prema našem mišljenju, fiksacijom se mogu liječiti samo akutna oštećenja, nastala kao rezultat jasne traume kod kojih je zadržana vijabilnost koštanohrskavičnog fragmenta.

U današnje vrijeme subjektivna procjena zdravlja putem strukturiranih upitnika za samoprocjenu zdravstvenog stanja trebala bi biti standardni postupak u gotovo svim istraživanjima u kojima se ocjenjuje ishod provedenog liječenja. Naime, poboljšanje kakvoće života bolesnika prepoznaje se kao krajnji cilj svakog liječenja. Ipak, većina dosadašnjih istraživanja o rezultatima liječenja OLT-a bavila se samo funkcionalnim ishodima, pri čemu je kakvoća bolesnikova života uglavnom zanemarivana. Također se pokazalo da postoje značajne razlike između liječnikove procjene bolesnikova stanja i procjene zdravlja samih bolesnika (25). Stoga smo u našem istraživanju određivali zbirnu komponentu tjelesnog i mentalnog zdravlja upitnika SF-36, koji je jedan od najraširenijih upitnika za analizu kakvoće života vezane sa zdravljem, pa se primjenjuje širom svijeta i u Hrvatskoj $(16,26)$. Rezultati zbirne komponente tjelesnog i mentalnog zdravlja dobiveni u našem istraživanju nalaze se u normalnim granicama za hrvatsku populaciju (17).

S obzirom na postignute rezultate nakon srednjoročnog praćenja možemo zaključiti da je artroskopska BMS tehnika mikrofraktura sigurna i učinkovita operacijska metoda za liječenje OLT-a u djece kod koje nije dostignuta koštana zrelost.

\section{Kratice:}

BMS - Bone Marrow Stimulation, stimulacija koštane srži

OLT - Osteochondral Lesion of the Talus, koštanohrskavično oštećenje talusa AOFAS - American Orthopaedic Foot and Ankle Society score, upitnik za procjenu stanja gležnja

SANE - Single Assessment Numeric Evaluation questionnaire, upitnik za procjenu stanja gležnja

$\mathrm{BH}-$ Berndt and Harty questionnaire, upitnik za procjenu stanja gležnja

SF 36 - Short Form 36 questionnaire, kratki upitnik od 36 pitanja za procjenu zdravlja

PCS - Physical Common Score, zbirna komponenta tjelesnog zdravlja MCS - Mental Common Score, zbirna komponenta mentalnog zdravlja MR - Magnetic Resonance, magnetska rezonancija

\section{NOVČANA POTPORA/FUNDING}

Nema/None

\section{ETIČKO ODOBRENJE/ETHICAL APPROVAL}

Odobrenje Etičkog povjerenstva Kliničkog bolničkog centra Zagreb/Approval by the Ethical Board of Clinical Hospital Centre Zagreb 


\section{SUKOB INTERESA/CONFLICT OF INTEREST}

Autori su popunili the Unified Competing Interest form na www.icmje.org/ coi_disclosure.pdf (dostupno na zahtjev) obrazac i izjavljuju: nemaju potporu niti jedne organizacije za objavljeni rad; nemaju financijsku potporu niti jedne organizacije koja bi mogla imati interes za objavu ovog rada u posljednje 3 godine; nemaju drugih veza ili aktivnosti koje bi mogle utjecati na objavljeni rad./All authors have completed the Unified Competing Interest form at www.icmje.org/coi_disclosure.pdf (available on request from the corresponding author) and declare: no support from any organization for the submitted work; no financial relationships with any organizations that might have an interest in the submitted work in the previous 3 years; no other relationships or activities that could appear to have influenced the submitted work.

\section{LITERATURA}

1. Berndt AL, Harty M. Transchondral fractures (osteochondritis dissecans) of the talus. J Bone Joint Surg Am. 1959;41:988-1020.

2. Canale ST, Belding RH. Osteochondral lesions of the talus. J Bone Joint Surg Am. 1980;62:97-102.

3. Flick AB, Gould N. Osteochondritis dissecans of the talus (transchondral fractures of the talus): Review of the literature and surgical approach for the medial dome lesions. Foot Ankle. 1985;5:165-85.

4. Zengerink M, Struijs PA, Tol JL, van Dijk CN. Treatment of osteochondral lesions of the talus: a systematic review. Knee Surg Sports Traumatol Arthrosc. 2010;18:238-46. doi: 10.1007/s00167-009-0942-6.

5. Bojanic I, Cerovecki T, Smoljanovic T, Ivkovic I, Trsek D, Boric I. Osteohondritis disekans gležnja. Liječ Vjesn. 2007;129:191-9.

6. Higuera J, Laguna R, Peral M, Aranda E, Soleto J. Osteochondritis dissecans of the talus during childhood and adolescence. J Pediatr Orthop. 1998;18:328-32.

7. Lam YK, Siow MH. Conservative treatment for juvenile osteochondritis dissecans of the talus. J Orthop Surg Res. 2012;20:176-80.

8. Letts M, Davidson D, Ahmer A. Osteochondritis dissecans of the talus in children. J Pediatr Orthop. 2003;23:617-25.

9. Perumal V, Wall E, Babekir N. Juvenile osteochondritis dissecans of the talus. J Pediatr Orthop. 2007;27:821-5.

10. Reilingh ML, Kerkhoffs GMMJ, Telkamp CJA, Struijs PA, van Dijk CN. Treatment of osteochondral defects of the talus in children. Knee Surg Sports Traumatol Arthrosc. 2013;9:2243-9. doi: 10.1007/s00167-013-2685-7.

11. Kumai T, Takakura Y, Higashiyama I, Tamai S. Arthroscopic drilling for the treatment of osteochondral lesions of the talus. J Bone Joint Surg Am. 1999;81:1229-35.

12. Karholm J, Hansson LI, Selvik G. Longitudinal growth rate of distal tibia and fibula in children. Clin Orthop Relat Res. 1984;191:121-8.
13. Kitaoka H, Alexander I, Adelaar R, Nunley J, Myerson M, Sanders M. Clinical rating systems for the ankle-hindfoot, midfoot, hallux and lesser toes. Foot Ankle. 1994;15:349-53.

14. Williams GN, Gangel TJ, Arciero RA, Uhorchak JM, Taylor DC. Comparison of the single assessment numeric evaluation method and two shoulder rating scales. Outcomes measures after shoulder surgery. Am J Sports Med. 1999;27:214-21.

15. Martin DF, Baker CL, Curl WW, Andrews JR, Robie DB, Haas AF. Operative ankle arthroscopy. Long-term follow-up. Am J Sports Med. 1989;17:16-23.

16. Buttanshaw $C$, editor. Tipping the balance towards primary healthcare network. Proceedings of the 10th anniversary conference of the Tipping the balance towards primary healthcare network. Goeteborg: The Nordic School of Public Health; November 13-16,1997, Goeteborg, Sweden.

17. Jureša V, Ivanković $D$, Vuletić $G$, et al. The Croatian Health Survey - SF-36: I. General quality of life assessment. Coll. Antropol. 2000;1:69-78.

18. Dipaola JD, Nelson DW, Colville MR. Characterizing osteochondral lesions by magnetic resonance imaging. Arthroscopy. 1991;7:101-4.

19. Marlovits S, Striessnig G, Resinger CT, et al. Definition of pertinent parameters for the evaluation of articular cartilage repair tissue with high-resolution magnetic resonance imaging. Eur J Radiol. 2004;52:310-9.

20. Marlovits S, Singer P, Zeller P, MandI I, Haller J, Trattnig S. Magnetic resonance observation of cartilage repair tissue (MOCART) for the evaluation of autologous chondrocyte transplantation: determination of interobserver variability and correlation to clinical outcome after 2 years. Eur J Radiol. 2006;57:16-23.

21. Becher C, Driessen A, Hess T, Longo UG, Maffulli N, Thermann H. Microfracture for chondral defects of the talus: maintenance of early results at midterm follow-up. Knee Surg Sports Traumatol Arthrosc. 2010;18:65663. doi: 10.1007/s00167-009-1036-1.

22. Imhoff AB, Paul J, Ottinger B, et al. Osteochondral transplantation of the talus: long-term clinical and magnetic resonance imaging evaluation. Am J Sports Med. 2011;39:1487-93. doi: 10.1177/0363546510397726.

23. Bruns J, Rosenbach B. Osteochondrosis dissecans of the talus. Comparison of results of surgical treatment in adolescents and adults. Arch Orthop Trauma Surg. 1992;112:23-7.

24. Schuh A, Salminen S, Zeiler G, Schraml A. Results of fixation of osteochondral lesions of the talus using K-wires. Zentralbl Chir. 2004;129:470-5

25. Janse AJ, Gemke RJ, Uiterwaal CS, van der Tweel I, Kimpen JL, Sinnema G. Quality of life: patients and doctors don't always agree: a meta-analysis. J Clin Epidemiol. 2004;57:653-61.

26. Ware JE Jr, Gandek B. Overview of the SF-36 Health Survey and the International Quality of Life Assessment (IQOLA) Project. J Clin Epidemiol. 1998;51:903-12. 


\title{
Operative treatment of osteochondral lesions of the talus in children
}

\author{
I. Bojanić, A. Jurina, D. Dimnjaković, T. Smoljanović
}

Literature on the operative treatment of osteochondral lesion of the talus in children is scarce. The aim of this study was to evaluate the mid-term clinical outcomes of arthroscopic bone marrow stimulation with microfracturing for the treatment of osteochondral lesion of the talus in skeletally immature children. Thirteen patients with osteochondral lesion of the talus, treated by arthroscopic bone marrow stimulation with microfracturing before skeletal maturity, were included in the study. At the evaluation visit, patient subjective satisfaction with the operation was assessed using the Berndt and Harty questionnaire, Single Assessment Numeric EvaIuation questionnaire and Martin questionnaire. Functional outcome was evaluated by using the American Orthopedic Foot and Ankle Society score. Short Form 36 questionnaire was used to assess the health related quality of life. The median patient age at the time of operation was 15 (range 13-16) years. The median time elapsed between the operation and evaluation was 5.6 (range 3.8-13.6) years. According to the Berndt and Harty questionnaire, ten patients reported good results and three patients fair results. Eleven patients had excellent or good results according to the Single Assessment Numeric Evaluation questionnaire. There was significant improvement in the postoperative American Orthopedic Foot and Ankle Society score as compared with the preoperative American Orthopedic Foot and Ankle Society score, with a mean increase of 35 points. The median Short Form 36 questionnaire physical and mental common scores were within the normal range for the Croatian population. In conclusion, arthroscopic bone marrow stimulation with microfracturing is a safe and effective method in the treatment of osteochondral lesion of the talus in skeletally immature children.

Keywords: arthroscopy; talus; child 